\title{
Risk and Resilience Factors of Divorce and Young Children's Emotional Well-Being in Greece: A Correlational Study
}

\author{
Christina Karela ${ }^{1} \&$ Konstantinos Petrogiannis ${ }^{1}$ \\ ${ }^{1}$ School of Humanities, Hellenic Open University, Patras, Greece \\ Correspondence: Karela Christina, School of Humanities, Hellenic Open University, Parodos Aristotelous 18, \\ 26335, Patras, Greece. Tel: 30-694-667-9048. E-mail: tina_karela@yahoo.gr
}

Received: May 21, 2018 Accepted: June 21, 2018 Online Published: June 29, 2018

doi:10.5539/jedp.v8n2p68 URL: http://doi.org/10.5539/jedp.v8n2p68

\begin{abstract}
This study examined the relation between some of the major risk and protective factors of divorce and young children's (4 to 7 years old) emotional well-being by adopting an ecosystemic approach based on Bronfenbrenner's theory and Kurdek's model of divorce. Children's well-being was assessed by a set of components such as attention, emotional and behavioural regulation, ability to take initiatives, positive relationships with others, parents' sensitive response to child's needs and cooperation with school. The study was conducted with a representative sample of 130 divorced parents from different regions in Greece. The questionnaire comprised of a cluster of scales and was completed by the custodial parent. Data supported that parent-child affective relationship, supportive co-parenting, parent's life satisfaction and the availability of supportive social groups were positively correlated to children's emotional well-being. On the other hand, pre-divorce intra-parental hostility, conflicts between the custodial parent and the child and child's feeling of rejection were related to less favourable developmental outcomes according to parental perception. The findings are discussed through the prism of the crucial role that divorce related factors play on the developmental process and their implications to divorce intervention programs.
\end{abstract}

Keywords: divorce, young children, emotional well-being, divorce process variables

\section{Introduction}

\subsection{Resilience in Children of Divorced Families}

Greece is among the European countries with the lowest rates of divorce. Recent domestic demographic data showed that although the number of marriages decreased in the years 1991 to 2014, the number of divorces has increased in recent decades from 0.6 up to 1.3 (crude number of divorce). An increase in the proportion of children who are growing in single-parent families was also apparent (Eurostat, 2015).

Lately there has been a shift in the divorce related literature from clinical perspectives which focused on pathology and dysfunctions to the positively focused construct of resilience. Although there is no consensus regarding its definition, resilience generally refers to patterns of positive adaptation during or following a significant adversity or risk that buffer individuals and allow them to "bounce back" to their previous level of well-being or even to attain a higher level of functioning (Greeff \& Van Der Merwe, 2004; Masten, Cutuli, Herbes, \& Reed, 2009 , p. 118). It entails two fundamental judgments: the first that the individual is "doing well" and the second that there is or has been some significant risk or adversity to overcome (Masten \& Coatsworth, 1998). Study of resilience requires systematic assessment of adversities in order to examine whether the available resources (protective factors) affect or interact with adversities determining the psychological outcomes in individuals (Hetherington \& Elmore, 2003). Moreover, diverse criteria have been used to judge satisfying levels of adaptation in studies of resilience. These include positive behaviors (e.g. social and academic competence, desired age-related behaviors and happiness), as well as the absence of negative feelings and behaviors, such as emotional distress or mental illness (Masten, Cutuli, Herbes, \& Reed, 2009, p. 118).

Resilience context is well-grounded in divorce research as parental separation and divorce has been identified as a significant stressor/adversity that children have to thrive despite the challenges that they may face. Thus investigating the factors that can enhance/ameliorate children's ability to cope with the challenge of divorce and promote resilience (protective factors), or on the other hand, impede their psychosocial development (risk factors) 
following the marriage disruption has prompted a considerable interest for the researchers. Studies in this field have produced a considerable but dispersed body of empirical findings regarding the relation among the major risk and protective factors of divorce and children's well-being and seem to use these findings with limited effectiveness in designing intervention programs focused on the members of divorced families. Even if the majority of researchers in the relevant field argues that multivariate explanations of children's well-being are necessary, a few have utilized a holistic approach including multiple factors in their study (see also Kurdek, 1988; Lengua, Wolchik, \& Braver, 1995).

\subsection{Ecological System Perspective of Divorce Related Factors}

Recent clinical and research practices have been attracted by an ecological approach introduced by Bronfenbrenner (1979) who described human development as occurring in an ecosystemic environment composed of five nested contexts (micro-, meso-, exo-, macro-, chronosystem (see, for example, Berk, 2000; Das, 2009; Kurdek, 1981; Petrogiannis, 2003). Inherent in this approach is the notion that changes occurring within any part of a context will affect changes in the total system. It is also emphasized that every context can provide children with the necessary potential for positive development and at the same time expose them to challenges and risks. Resources and adversities are seen as dynamically affecting each other over time, thus ecosystemic perspectives could capture more comprehensively this process and advance our understanding of the influence of vulnerability and protective factors on the resilience of children experiencing significant adversities.

Drawing upon Bronfenbrenner's work, Kurdek (1981) claimed that divorce-related experiences need to be understood in terms of hierarchically embedded psychological, familial, social and cultural contexts. He developed a model for integrating the research on children's divorce adjustment, which is presented as an interaction among four components: (a) the macrosystem, which includes cultural beliefs, values, and attitudes surrounding modern family life, (b) the exosystem, which includes the stability of the post-crisis environment and the social support available in the divorced family, (c) the microsystem, which defines the nature of change in family interaction, the overall functioning between pre- and post-crisis and support systems available to the child and (d) ontogenic system, which incorporates the child's individual psychological capacity for dealing with stress and change (1981, p.856). The appeal of Kurdek's model lies in its inclusion of cultural, family as well as individual variables that determine the final outcome in children's adaptation to stressors of divorce. In each component, risk factors and resilience resources have been identified to exacerbate or mitigate the effects of divorce stressors on children competence, and have been viewed as mutually influencing each other within and across levels.

Thus, the ecological system perspective and Kurdek's (1981) paradigm of divorce seem to provide a framework with the help of which researchers can interpretively organize the relevant commonly studied factors of divorce process in order to explore the potential relationships that may exist between a number of risk and protective factors attributed to the previously mentioned components/levels and, according to the review of the relevant literature, they are associated with children's adjustment and well-being post-divorce, emphasizing the major role that they play to children's development.

\subsection{Risk and Protective Factors in Children of Divorce}

In spite of accumulating research findings, a fierce debate continues on the effects of parental divorce on social and cognitive achievements in children (Amato \& Keith, 1991; Hetherington \& Stanley-Hagen, 1999; Leon, 2003). Comparing children from both intact and divorced families, a considerable agreement in longitudinal studies over the past few decades exists that suggests that children who had dealt with parental divorce exhibited lower levels of well-being and an increased risk for the development of adjustment problems, such as social competence deficits, conduct problems, lower self-esteem and increased risk of school failure (Amato, 2000; Emery, 1999; Furstenberg \& Kiernan, 2001; Greene, Anderson, Forgatch, DeGarmo, \& Hetherington, 2011; Hetherington, 1999; Simons, Lin, Gordon, Conger, \& Lorenz, 1999). Not only there is a consensus on the presence of discrepancies between children of divorced and intact families, but also there is a great deal of inconsistency in the relevant literature as well (Amato, 1994). Moreover, Emery (1988) acknowledged that although divorce has been associated with a number of negative outcomes, children with serious problems were not markedly overrepresented among divorced families (p. 70). Specifically, about 20-25\% of children in divorced families, compared to $10 \%$ of children in intact families, demonstrate severe emotional and behavioral problems (Hetherington, 1993; McLanahan, 1999).

A number of conditions that put children from divorced families at greater risk for developing adjustment problems have been recorded, such as high levels of interparental conflicts pre and post-divorce, physical or/and emotional absence of one parent (e.g. lack of or intermittent contact with the non-custodial parent), loss of important relationships, neglect and diminished parental responsiveness to the children's needs, vague explanations about the causes of divorce, litigation, one's parent remarriage, stressful life events (e.g. multiple 
moves), lack of a supportive network, financial difficulties in the single parent family and problems in parents' mental and physical health after separation (Amato, 2000, 2001; Bauserman, 2002; Finkelhor, Ormrod, \& Turner, 2007; Green, Goodman, Krupnick, Corcoran, \& Petty, 2000; Grych, 2005; Hetherington, 2003; Katz \& Woodin, 2002; Kelly, 2000; Kelly \& Emery, 2003; Nair \& Murray, 2005; Nunes-Costa, Lamela, \& Figueiredo, 2009; Rhoades, 2008).

Regarding the duration of the negative effects of divorce in children it has been suggested that some of the difficulties children confronted might be temporary (e.g. during the crisis period) (Wallerstein \& Lewis, 1998), while others may persist over time and others may have been present long before the marriage breakdown, since it is not the divorce per se that can harm children but the stressful condition that preceded it (Strohschein, 2005; Sun $\& \mathrm{Li}, 2002$ ). Researchers, however, mentioned that children's negative emotion (e.g. anger, resentment, demandingness, noncompliance, anxiety, and depression) and adjustment problems tented to diminish over a period of approximately two years after the divorce (Guidubaldi, Perry, \& Nastasi, 1987; Hetheringto*n, Cox, \& Cox, 1982) and three to five years following remarriage (Hetherington \& Stanley-Hagan, 2002), as soon as the changes in family structure were accepted.

According to recent empirical evidence divorce either did not have unpleasant consequences for the children in all cases or some of them possess the potential for achieving positive outcomes or even benefit from their new life situation, despite the family adverse transition due to divorce (Amato, 2001; Babalis, Xanthakou, Papa, \& Tsolou, 2011; Greeff \& Van Der Merwe, 2004; Greene et al., 2011; Hetherington \& Stanley-Hagan, 1999; Kelly \& Emery, 2003; Rogers, 2004; Rushena, Prior, Sanson, \& Smart, 2005; O’Connor, 2003). This is not to underestimate the apprehension, painful feelings, sorrow and grief that many children experience in response to their parents' separation, however, in the absence of new stresses and adversity, the vast majority of children are able to cope with the challenges of divorce, indicating that resilience is a normative outcome (Amato, 2000; Hetherington \& Stanley-Hagan, 1999; McLanahan, 1999). Not to mention that about $40 \%$ of the children of divorced families, especially those from conflicted and violent environments, seemed to adjust better following the divorce, compared with counterparts who have not experienced interparental conflicts pre or post-divorce (Strohschein, 2005). Hetherington and Kelly (2002) maintained that beyond the risk that divorce put to children, in the long run, it may also provide parents and children with beneficial experiences, such as an escape from an aversive, conflictual, unsatisfying family situation, the opportunity to build more fulfilling and happier intimate relationships, a move to a more harmonious family environment, the improvement of the problem-solving skills and the potential for personal development (Dreman, 2000; Greene et al., 2011; Kelly, 2000).

A number of protective factors that enhance children to cope better with the parents' divorce have been recognized. These include positive personality traits (e.g. easy temperament, an internal locus of control, and active coping styles), low interfamilial conflicts and supportive relationships within the family, parents' common attitudes toward upbringing, authoritative parenting, environmental stability, warm parent-child relationship, well-adjusted parent, frequent communication with the non-residential parent, social support network (e.g. peers, school, a wider family), government services to provide financial and psychological support to divorced parents and their children (Amato, 2000; Gagnè et al., 2007; Frisby et al., 2012; Hetherington, 2003; Kelly \& Emery, 2003; Leon, 2003; Linker, Stolberg, \& Green, 1999).

Identifying factors that enhance risk or resilience following divorce seems to be especially salient for children confronting the challenges of divorce and life in a single-parent family. Furthermore, it could allow researchers and practitioners to target specific individuals who are in need of post-divorce interventions or counseling. An understanding of the different responses to divorce and who will respond in particular ways can also pose a significant contribution to the field of clinical and therapeutically work with children and youth from divorced families providing comfort and support following marriage dissolution (Kincaid \& Caldwell, 1995).

\subsection{The Aim of This Study}

The current study attempted, through an explorative analytical procedure, to investigate the relation between some of the major risk (e.g. parents' hostility, stressful life events, parental stress) and protective (e.g. quality of parent-child relationship, supportive groups, parents' life satisfaction) factors that have been identified in previous empirical literature to be related to children's emotional well-being in divorce-related situations. Factors encompassed in three ecosystemic contexts as illustrated in the Figure 1 were used to frame this study. Children's emotional well-being was assessed by a set of factors that have been evolved in the divorce and resilience-related research literature, such as attention, emotional and behavioural regulation, ability to take initiatives, positive relationships with others, parents' sensitive response to child's needs and cooperation with school, with parents as informants. 


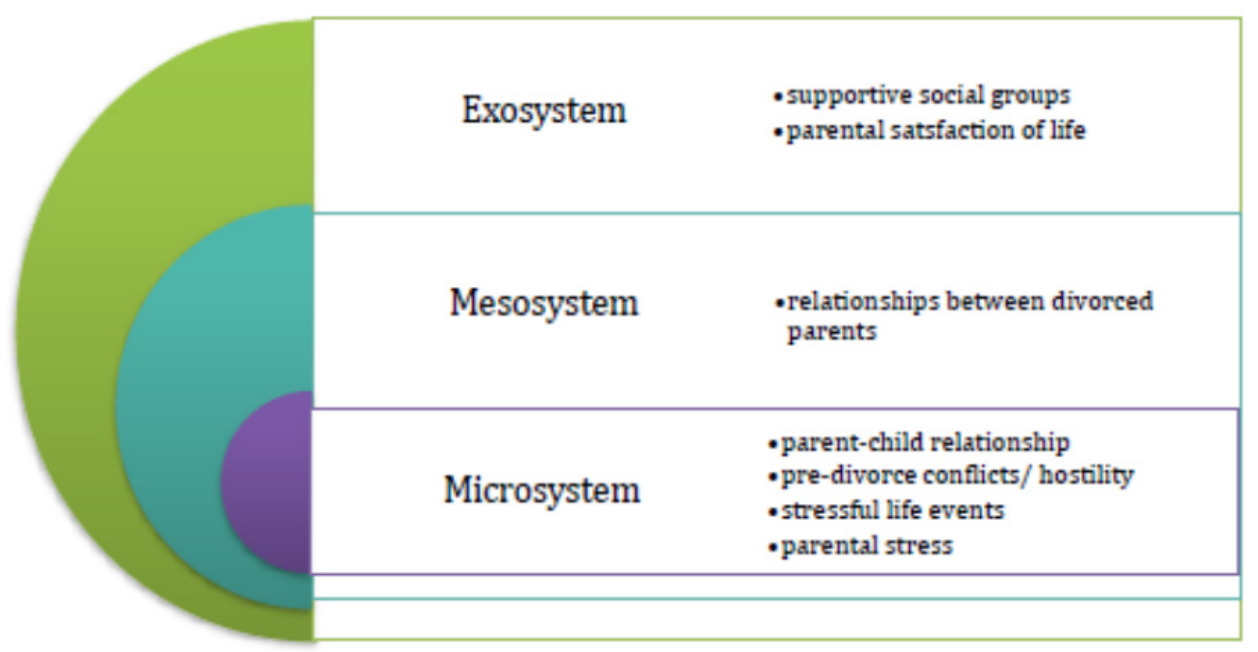

Figure 1. Ecological classification of divorce related factors included in the study

The core research question posed was "What is the relation between a number of risk and protective factors attributed to micro-, meso- and exo-systemic level and young children's well-being related measures almost one year after divorce based on their parent's perceptions?"

\section{Method}

\subsection{Participant Characteristics and Sampling Procedures}

The study was conducted with a sample of 130 divorced parents who had the custody of the child (114 mothers and 26 fathers) and were the principal informants with reference to the instruments used in the study concerning the child, the family, and themselves as parents. A number of participants' recruiting strategies were applied due to the particularities of the project. The parents were recruited from organizations for divorced families, kindergartens and related groups in the social media (facebook), following a type of snowball sampling procedure. Only participants who had been divorced within at least one year were retained for the study. The parents' age ranged from 24 to 49 years $(\mathrm{M}=36.9, \mathrm{SD}=4.28)$ and they were living in different regions of the Greece territory. Regarding children ( 56 females and 74 males), their age ranged between 3.6 to 7.25 years, with a mean age of 5.7 years, which was a principal case selection.

Participants had been married for an average of 7 years (range: $1-21$ years, $\mathrm{SD}=4.47$ years) and divorced in an average of 3 years prior to the period of study (range: 11 months to 8 years, $\mathrm{SD}=23.86$ months). The mean time that had passed since the parents signed the divorce papers was about three years (range: 11 months to 7 years). In $62.7 \%$ of the divorce cases the parents were divorced by mutual consent, while $37.3 \%$ of them chose a dispute resolution. Of the participants, $59.4 \%$ of the divorcees were parents of one child, $30.5 \%$ had two children, $7.8 \%$ had three children, $1.6 \%$ had four children and another $0.8 \%$ had five or more children.

\subsection{Procedure and Measures}

Due to the sensitive data of the target families in terms of sampling accessibility and criteria for inclusion (e.g. age of children, non-referenced for any behavioural or other kind of problem etc), the researchers approached a number of organisations/contexts related to divorced families. Potential participants were asked to contact the researcher if they were interested to participate and were then sent an electronic or printed form of the questionnaire including a consent form. For the current study the questionnaire was constituted by a cluster of scales, appropriately translated, piloted and adjusted from former research studies or developed for this particular one. Each scale was chosen appropriately so as to present sound psychometric properties and to provide a sufficient measure of the selected constructs/factors. In addition, all the necessary psychometric properties and procedures were applied accordingly. For the needs of the current study the following scales were used:

Children's emotional well-being was assessed by a modified version of the "Affective Wellness Scale for preschool children" (Petrogiannis \& Bardos, 2011) which was designed to be completed by parents. This scale consisted of 53 items which fell into six domains: attention, emotional and behavioural regulation, ability to take initiatives, positive relationships with others, parents' sensitive response to child's needs and cooperation with school. It was 
scored using a 4-point rating scale ranging from "never" to "always". Cronbach reliability indices for the six domains ranged from 0.76 to 0.93 (e.g. attention, $\alpha=0.91$; emotional and behavioural regulation, $\alpha=0.84$; ability to take initiatives, $\alpha=0.76$; positive relationships with others, $\alpha=0.91$; parents' sensitive response to child's needs, $\alpha=$ 0.93; and cooperation with school, $\alpha=0.85$ ).

Pre-divorce overt hostility was indexed by parental report to O'Leary-Porter's "Over Hostility Scale" (Porter \& O'Leary, 1980). It consisted of 10 items measured by a 5-point rating scale ranging from "never" to "very often". The scale is designed to assess the frequency that parents openly argue and it contained various forms of marital hostility (e.g. quarrels, physical abuse) that may have occurred in the presence of their children. Cronbach $\alpha$ for this scale was 0.86 . Test-retest reliability in a sample of 65 parents who participate in volunteer, community programs was 0.96 (Porter \& O'Leary, 1980).

The quality of relation between divorced parents was assessed by using the "Quality of Co-parental Communication Scale" (Ahrons, 1981). The constructs covered by 10 items, were divided in two subscales and scored in a 5-point Likert scale items (ranging from "never" to "always"). One subscale refers to co-parental interaction and support (e.g. frequency of conversations between parents about the child raising, willingness to accommodate changes in visitation) and the other subscale refers to co-parental conflict (e.g. the frequency, hostility, tension of arguments about parenting), as well as differences in beliefs over childrearing. Cronbach's alphas for co-parental interaction/support and conflict ranged from 0.82 to 0.91 , respectively.

Parent-child quality of relationship was measured using the "Parent-Child Emotional Relationship" subscale from the "Home and Family Questionnaire" (HFQ) (Pierce, Alfonso, \& Garrison, 1998). The subscale consisted of 16 items clustered into five factors: parent-child conflict, parental warmth vs. physical punishment, emotional openness, parental hostility and parent-child communications. Each item was scored using a 4-point Likert scale ranging from "never" to "very often". The subscale demonstrated adequate reliability $(\alpha=0.67)$ and appropriate construct validity (e.g. positive correlation with authoritative parenting).

Stressful life events in childhood were measured by a modified version of the "Life Events Schedule" (CLES) (Coddington, 1999). The CLES for preschool children refers to 30 events from different areas such as education (e.g. beginning of kindergarten), parents (e.g. mother started working), family (e.g. birth of a sibling), or health (e.g. sever illness that required hospitalization). The current study comprised 26 life events as those referred to separation and divorce were excluded. The total score of stressful life events was calculated by summing the weighted values of the events that the participants have checked as being happened within at least one year after divorce. Test-retest reliability in a sample of young children ranged from 0.87 to 0.89 .

Parental Stress was assessed by using a subscale of the section entitled "subjective parenting stress" in the "Nijmegen Child-Rearing Situation Questionnaire" (NCSQ) (Robbroeckx \& Wels, 1989). The questions are scored based on a Likert type scale with five alternatives ranging from "agree completely" (1) to "disagree completely" (5). The items were reversed appropriately so that higher scores indicate lower levels of stress. Results from the Dutch psychometric testing of the NCSQ's subscale indicated good psychometric properties (Weis and Robbroeckx, 1996), internal consistency ranged from 0.68 to 0.92 and correlation coefficients for test-retest ranged from 0.60 to 0.94 .

Supportive social groups were assessed by the "Social Support Scale" (Petrogiannis, 1995). It's a self-completion questionnaire of 10 items asking about social contact and extent of social network. Reliability indices estimated as moderate (0.67) in Greek studies.

Parental subjective feeling of satisfaction of life was measured by the "Life Satisfaction Inventory" (LSI) devised in Greek by Fountoulakis, Iakovidis, Iakovidis, Xristofidis, and Ierodiakonou (1997). The inventory is composed by 13 items that cover almost all the aspects of individual's life (e.g. general well-being, family life, financial status and job, mental and general health). Items are answered in a 5-level scale ranging from "very displeased" to "very pleased". The Greek translated version of the scale showed good reliability $(\alpha=0.86)$, which represented an equal reliability coefficient as has been shown by its constructors.

\section{Analysis}

Correlation analysis between each dimension of the perceived emotional well-being of young children (attention, emotional and behavioural regulation, ability to take initiatives, positive relationships with others, parents' sensitive response to child's needs and cooperation with school) and the risk and protective factors organized in micro-, meso- and exosystem context (see Figure 1) were examined and presented in Tables 1 and 2. 
Table 1. Correlations between selected factors of divorced families' microsystem and perceived emotional well-being of children

\begin{tabular}{|c|c|c|c|c|c|c|c|c|}
\hline \multirow{2}{*}{ Dimensions of emotional well-being } & \multicolumn{8}{|c|}{ Factors represented in microsystem } \\
\hline & (1) & (2) & (3a) & $(3 b)$ & $(3 \mathrm{c})$ & $(3 \mathrm{~d})$ & $(3 \mathrm{e})$ & (4) \\
\hline Attention & -0.15 & -0.06 & $-0.27 * *$ & $0.33 * *$ & -0.09 & 0,17 & $-0.25 * *$ & $0.28 * *$ \\
\hline Emotional and behavioural regulation & $-0.30 * *$ & 0.03 & $-0.28 * *$ & $0.36 * *$ & -0.08 & 0.15 & $-0.46 * *$ & $0.49 * *$ \\
\hline Ability to take initiatives & -0.02 & 0.04 & -0.13 & $0.25 * *$ & -0.02 & 0,13 & $-0.39 * *$ & $0.28 * *$ \\
\hline Positive relationships with others & $-0.27 * *$ & -0.08 & $-0.20 *$ & $0.32 * *$ & -0.16 & 0.13 & $-0.46^{* *}$ & $0.36^{* *}$ \\
\hline Parents' sensitive response to child's needs & $-0.26 * *$ & 0.02 & $-0.31 * *$ & $0.37 * *$ & -0.03 & $0.27 * *$ & $-0.25 * *$ & $0.30 * *$ \\
\hline Cooperation with school & -0.10 & -0.5 & 0.09 & 0.05 & $0.26 * *$ & $0.31 * *$ & -0.04 & 0.01 \\
\hline
\end{tabular}

Note. (1) pre-divorce conflicts-hostility, (2) stressful life events, (3a) parent-child conflict [parent-child relationship], (3b) parental warmth vs. physical punishment [parent-child relationship], (3c) emotional openness [parent-child relationship], (3d) parent-child communications [parent-child relationship], (3e) parental hostility [parent-child relationship], (4) low levels of parental stress.

$* * \mathrm{p}<0.01$.

With regard to the family factors of the microsystem (see Table 1) the results indicated that stressful life events were not related to any of the factors of emotional well-being. However, children's paid attention and emotional or/and behavioural regulation both had negative association with parent-child conflicts and parental hostility towards the child and positive association with parental warmth and low levels of parental stress. Ability to take initiatives was related negatively to parental hostility and positively to parental warmth and low levels of parental stress. Positive relationships with others were negatively correlated to pre-divorce hostility, parent-child conflicts and parental hostility and were positively related to parental warmth and low levels of parental stress. Negative association was found between parent's sensitive response to child's needs and pre-divorce hostility, parent-child conflicts and parental hostility, while there was a positive association with parental warmth, parent-child communication and low levels of parental stress. Lastly, a positive correlation was found between cooperation with school with emotional openness and parent-child communication.

Table 2. Correlations between selected family factors of meso- and exosystem and perceived emotional well-being of children

\begin{tabular}{|c|c|c|c|}
\hline \multirow{2}{*}{$\begin{array}{l}\text { Dimensions of emotional } \\
\text { well-being }\end{array}$} & \multirow{2}{*}{$\begin{array}{l}\text { Family factors represented in } \\
\text { mesosystem }\end{array}$} & \multicolumn{2}{|c|}{ Family factors represented in exosystem } \\
\hline & & $\begin{array}{l}\text { supportive social } \\
\text { groups }\end{array}$ & $\begin{array}{l}\text { parental satisfaction of } \\
\text { life }\end{array}$ \\
\hline attention & 0.02 & $0.21 *$ & $0.37 * *$ \\
\hline $\begin{array}{l}\text { emotional and behavioural } \\
\text { regulation }\end{array}$ & $0.21 *$ & $0.40 * *$ & $0.49 * *$ \\
\hline ability to take initiatives & 0.17 & $0.25 * *$ & $0.39 * *$ \\
\hline positive relationships with others & $0.32 * *$ & $0.25 *$ & $0.39 * *$ \\
\hline $\begin{array}{l}\text { parents' sensitive response to } \\
\text { child's needs }\end{array}$ & -0.03 & $0.22 *$ & $0.31 * *$ \\
\hline cooperation with school & -0.02 & $0.18 *$ & -0.01 \\
\hline
\end{tabular}

Note. ${ }^{*} \mathrm{p}<0.05,{ }^{* *} \mathrm{p}<0.01$.

In Table 2 a statistically significant positive correlation was observed between supportive relationships between divorced parents (mesosytem) with children's emotional and behavioural regulation, as well as the development of positive relationships with others. Regarding exosystem's factors, the analysis showed that supportive social 
groups were positive related to all the dimensions of emotional well-being. Parental life satisfaction was positively correlated to the most dimensions of emotional well-being with the exception of the "cooperation with school" factor where no statistically significant correlation was found.

\section{Discussion}

\subsection{Summary of the Main Findings}

Identifying the risk and protective conditions surrounding a divorce and proposing an explanatory concept to understand the association between parental divorce and children's psychological well-being has been a longstanding, major issue in the relevant divorce literature. Although research in the past decades has yielded considerable information in this field, issues that need further investigation are still remaining. Furthermore, some of the schemes that have been proposed to better understand the effect of divorce on children's emotional well-being do not seem to reflect its complexity. To this end, the ecosystemic approach can provide some further explanation of the results of empirical studies.

This study which is based on an ecosystemic perspective and makes use of Kurdek's (1981) model of divorce as a methodological framework, representing the divorce related variables in ecological systems, revealed that a number of risk and protective factors from different contexts were linked with some measures of children's well-being about a year after their parents' divorce. Some of them, such as hostility, rejection and conflicted relationships can increase the likelihood of the development or maintenance of various cognitive and emotional problems, while others enhance children's resilience in terms of exhibiting positive outcomes to some components of well-being besides the stressors of divorce. These factors include a warm and authoritative parenting, supportive patterns of communication between the ex-husbands, single-parent's satisfaction of life, low parental stress and available social networks (grandparents, friends, teachers etc.). Hence, an element that this study has attempted to add to the existing literature is the approach of risk and protective factors of divorce that are related to children's well-being under the framework of the ecological systems perspective. Consequently, the significant findings for each level are outlining briefly.

\subsection{Factors Represented in the Microsystem}

In the divorce related literature, pre-divorce conflicts were strongly related to children's well-being and were subsequently associated with a wide range of deleterious outcomes for children (Amato, 2001; Barnes, 1999; Hetherington \& Stanley-Hagan, 1999; McIntyre, Heron, McIntyre, Burton, \& Engler, 2003; Rushena et al., 2005; Vandewater \& Lansford, 1998). Confirming previous findings, a negative correlation between parental conflicts before the divorce with children's ability to regulate themselves, their behavior and to develop positive interpersonal skills was found. Furthermore, the higher conflicted the family environment was before the marriage dissolution, the less the divorced parents were found to be adequate to meet their children's needs. Existing studies have, in addition, shown that children from conflicted environments, even after parental divorce, exhibited: (a) externalized and internalized reactions (e.g. aggression, impulsivity, anxiety, emotional difficulties), b) emotional disruption, reduced self-regulation and even pathological or psychosomatic symptoms, c) difficulties in social skills and relationships with other children, d) lower self-esteem and e) learning difficulties or reduced school performance (Amato, 2001; Leon, 2003; McIntosh, Burke, Dour, \& Gridley, 2009; McLoyd, Harper \& Copeland, 2001; Pruett, Williams, Insabella, \& Little, 2003).

In keeping with previous studies, the quality of parent-child relationship has also been found to play a crucial role in either protecting children or making them more vulnerable to adverse consequences from the stresses associated with parental divorce (Dunn, Cheng, O’Connor, \& Bridges, 2004; Golombok, 2000; Hakvoort, Bos, VanBalen, \& Hermanns 2011; Hetherington \& Stanley-Hagan, 2002; Rogers, 2004; Videon, 2002). In the present study affectionate interactions and the avoidance of punishment were positively linked to all dimensions of the emotional well-being of children, with the exception of communication with non-family contexts where no significant correlation was found. On the contrary, the analysis showed that child's sense of hostility and rejection was negatively linked to all dimensions of child's emotional well-being. It was suggested that the more hostile, distant and rejecting the caregiver is and the more distortions occur between $\mathrm{him} / \mathrm{her}$ and the child, the more difficult it is for children to control their attention, regulate their behavior and feelings, take initiatives and exhibit pro-social behaviors. With regard to parents they behaved with less sensitivity and responsiveness to their child's needs. The emotional openness of the parent to the child was positively related to cooperation and frequent contact with non-family contexts, such as school. On the other hand, no statistically significant correlation was found between parent-child relationship and communication with non-family contexts. Concerning effective parent-child communication it was positively related to the relational dimensions of emotional well-being, such as the parental responsiveness to the child's needs and the communication with non-family contexts. In other words, it seemed 
that the closer the parent-child relationship was, the better the parents responded to the child's needs and they also kept a good cooperation with the school staff.

The findings of the current study reinforced previous research arguing that the quality of parenting was associated with children's socialization and self-regulation (Lengua et al., 2000). The protective function of authoritative parents who are warm, supportive, communicative and responsive to their children's needs and who exert firm, consistent, and reasonable control and close supervision is considered particularly salient for children in families going through their parents' marital transitions and other situations involving multiple stressors (Amato, 2001; Hetherington, 1993; Hetherington \& Elmore, 2003). Weaver and Schofield (2015) supported that authoritative parental practices after divorce and warm parent-child relationship could provide better and faster adjustment for divorced children, while mother's sensitivity could preserve them from the harmful effects of divorce. Hence, the divorced parents should try to minimize post-divorce conflicts, not to encourage alliances with one parent or alienation from the other parent and lastly, to avoid putting the child in the middle of their own disputes (Amato \& Gilbreth, 1999; Lansford, 2009).

Few studies have investigated the association between divorced children's well-being and parental stress, although our findings presented strong evidence about it. More specifically, the less the divorced parents got stressed by their role the more the children were able to control their attention, achieve emotional regulation and social skills, were enhanced to take initiatives, interact with sensitivity with their parents who believed that they had a better communication with school. According to Ang (2008) parental stress was often associated with fewer adaptive parenting behaviors and more difficulties for children. Previous studied have addressed that the positive parenting and parents' ability to respond adequately to their role could enhance their mental health and by extension their children's well-being (Miller, Gordon, Daniele, \& Diller, 1992; Thompson, Gustafson, Hamlett; \& Spock, 1992). Opposing, empirical evidence have shown that parental stress is associated with less effective parenting, lower levels of social and psychological competence in children and disrupted family systems (Anthony, Anthony, Glanville, Naiman, Waandersm \& Shaffer, 2005; Crnic, Gaze, \& Hoffman, 2005).

\subsection{Factors Represented in the Mesosystem}

Numerous of studies in divorce related literature have shown that divorcees' relationships after separation had a great contribution to children's emotional well-being (Clarke-Stewart \& Brentano, 2006; Nunes-Costa et al., 2009). In this particular study the supportive relationships between the ex-husbands aftermaths of divorce were positive related to children's behavioral or emotional regulation and social competence, such as the ability to develop positive relationships with others. Some other interesting research findings suggested that children experience fewer behavioral problems or internalized responses when parents cooperate after divorce, support each other in their parental roles and effectively resolve their disputes through compromise and negotiation rather than express hostility (Adamsons \& Pasley, 2006). On the contrary, post-divorce conflicts and lack of mutual consent and trust between divorced parents are two of the factors that have consistently been associated with negative developmental outcomes for children (Amato, 2000; Buchanan, Maccoby \& Dornbusch, 1996; Vandewater \& Lansford, 1998).

\subsection{Factors Represented in the Exosystem}

Our findings suggested that the available social support and parental life satisfaction are related to young children's emotional well-being. That is, when parents feel that supportive social groups are present and the more they are satisfied with their life, more positive emotions and better adjustment after divorce occur in children. Many researchers have highlighted the protective effects of social support networks on the divorced family (Amato, 2000; Chen \& George, 2005; Hetherington, 1999; Hetherington \& Kelly, 2002; Kelly, 2000; Kelly \& Emery, 2003; Miller, Smerglia, Gaudet, \& Kitson, 1998). Support can be provided by the parents, members of the wider family, friends, teachers, consultants and others. Moreover, Clarke-Stewart et al. (2000) concluded that young children of divorce could be resilient if their mothers are able to provide them with emotional support and security, are highly educated, economical stable and non-depressive. Lastly, our findings are also consistent with the position supported in several studies that the more adapted and supportive parents are after the divorce and the better they control their life the higher is the estimated emotional well-being of children (Belsky, 1993).

\section{Conclusions and Recommendation}

Regarding children's well-being after divorce, researchers' attention has primarily focused on factors relating to the microsystem of the family (e.g. conflicts, parent-child relationship). However, it is well understood that the explanation of the factors that can affect children's development extends from a micro-systemic perception of the family to a macro-systemic perspective. In particular, not only the processes taking place within the family system 
but also the dynamic interactions between factors from different contexts appear to play a crucial role in the psychosocial adjustment of children.

The current study indicated that a number of factors are related to children's well-being. More specifically, data supported that at the level of family microsystem affection, warm parent-child communication and the absence of parental stress were positively correlated to children's emotional well-being. Interparental hostility before the divorce and child's feeling of rejection by the parent who had the custody were related to less favourable outcomes. Stressful life events were not related to any of the dimensions of emotional well-being. The supportive co-parenting was related to the children's ability of emotional regulation and social competence (mesosytem). Lastly, the availability of supportive social groups and parent's life satisfaction were positively related to children's emotional well-being (exosystem). The results were also in accordance with other previous research undertaken in the international field. For example, Gately and Schwebel (1992) found that children's positive adjustment after parental divorce was related to: a) child's sex and age at the moment of divorce, b) child's temperament, social competence and problem solving skills, c) the quality of parental communication and interactions pre- and post-divorce, d) mother's physical and emotional health, e) legal arrangements for the custody, f) remarriage, g) stressful life events, h) divorced family's income reduction and i) social support.

There are potentially many factors that can be examined in order to advance our understanding of the divorce-related conditions that determine children's developmental progress. Future researchers can possibly examine: a) ontogenetic factors (e.g. child's cognitive abilities, temperament and problem-solving skills), b) factors of the school's microsystem (e.g. the quality of relationships with peers or teachers, c) factors of the exosystem, such as changes in the marital status of a parent (e.g. romantic relationships or remarriage) and (d) macro-system factors, as for example custody arrangements, in order to render the association of divorce/separation with child outcome readily apparent.

Despite this study's contributions to the related literature on the relationships between risk and protective factors of divorce from different ecosystemic contexts limitations exist. First, the resultant number of participants, although we turned to a focused and targeted population group, was relatively small. Enlarging sample size in a future research effort would give safer place for more advanced statistical analysis that may reveal the complex interrelationships among variables. Also, our insight in the factors that are related to children's long-term adjustment to divorce stressors would benefit from longitudinal research designs.

On the other hand, considering the major findings it is suggested that children's difficulties after divorce can be modifiable by interventions which aimed to empower parents'empathy, affection and acceptance when interacting with children, help them to resolve arguments with the other parent and to avoid putting children in the middle of their own conflicts (Tschann, Johnston, Kline, \& Wallerstein, 1990). The more the children feel that they are loved and can trust both parents to be a source of emotional support, the better developmental outcomes they exhibit (Umberson, 1992). Concluding, developing intervention programs for children and parents from divorced families by which positive outcomes can be achieved should be the next important step for resilience research.

\section{References}

Adamsons, K., \& Pasley, K. (2006). Co-parenting following divorce and relationship dissolution. Handbook of divorce and relationship dissolution. In M. A. Fine \& J. H. Harvey (Eds.), Handbook of divorce and relationship dissolution (pp. 241-261). New York/London: Routledge-Taylor \& Francis.

Ahrons, C. R. (1981). The continuing co-parental relationship between divorced spouses. American Journal of Orthopsychiatry, 51, 315-328. https://doi.org/10.1111/j.1939-0025.1981.tb01390.x

Amato, P. R. (1994). Life-span adjustment of children to their parents' divorce. The Future of Children, 4(1), 143-164. https://doi.org/10.2307/1602482

Amato, P. R. (2000). The consequences of divorce for adults and children. Journal of Marriage and the Family, 62, 1269-1287. https://doi.org/10.1111/j.1741-3737.2000.01269.x

Amato, P. R. (2001). Children of divorce in the 1990s: an update of the Amato and Keith (1991) meta-analysis. Journal of Family Psychology, 15, 355-370. https://doi.org/10.1037/0893-3200.15.3.355

Amato, P. R., \& Gilbreth, J. G. (1999). Nonresident fathers and children's well-Being: A meta-analysis. Journal of Marriage and Family, 61(3), 557-573. https://doi.org/10.2307/353560

Amato, P. R., \& Keith, B. (1991). Parental divorce and adult well-being: A meta-analysis. Journal of Marriage and the Family, 53, 43-58. https://doi.org/10.2307/353132

Ang, R. P. (2008). Dysfunctional parenting behaviors and parenting stress among mothers of aggressive boys. 
Child \& Family Behavior Therapy, 30, 319-336. https://doi.org/10.1080/07317100802483181

Anthony, L. G., Anthony, B. J., Glanville, D. N., Naiman, D. Q., Waandersm C., \& Shaffer, S. (2005). The relationships between parenting stress, parenting behaviour and preschoolers' social competence and behaviour problems in the classroom. Infant and Child Development, 14, 133-154. https://doi.org/10.1002/icd.385

Babalis, T., Xanthakou, Y., Papa, C., \& Tsolou, O. (2011). Preschool age children, divorce and adjustment: a case study in Greek kindergarten. Electronic Journal of Research in Educational Psychology, 9(3), 1403-1426.

Baltes, P. B., Reese, H. W., \& Nesselroade, J. R. (1988). Life-span developmental psychology: Introduction to research method (2nd ed.). Hillsdale, NJ: Erlbaum.

Barnes, G. G. (1999). Divorce transitions: Identifying risk and promoting resilience for children and their parental relationships. Journal of Marital and Family Therapy, 25, 425-441. https://doi.org/10.1111/j.1752-0606.1999.tb00260.x

Bauserman, R. (2002). Child adjustment in joint-custody versus sole custody arrangements: a meta-analytic review. Journal of Family Psychology, 16, 91-102. https://doi.org/10.1037/0893-3200.16.1.91

Belsky, J. (1993). Etiology of child maltreatment: A developmental-ecological analysis. Psychological Bulletin, 114(3), 413-434. https://doi.org/10.1037/0033-2909.114.3.413

Berk, L.E. (2000). Child development, (5th ed, pp. 23-38). Boston: Boston Allyn and Bacon.

Bronfenbrenner, U. (1979). Contexts of child rearing. American Psychologist, 34, 844-858. https://doi.org/10.1037/0003-066X.34.10.844

Buchanan, C. M., Maccoby, E. E., \& Dornbusch, S. M. (1996). Adolescents after divorce. Cambridge, MA: Harvard University Press.

Chen, J., \& George, R. A. (2005). Cultivating resilience in children from divorce families. The Family Journal: Counseling and Therapy for Couples and Families, 20(10), 1-4.

Clarke-Stewart, A., \& Brentano, C. (2006). Divorce: Causes and consequences (Current Perspective in Psychology). New Haven, CT: Yale University Press.

Clarke-Stewart, K. A., Vandell, D. L., McCartney, K., Owen, M. T., \& Booth, C. L. (2000). Effects of parental separation and divorce on very young children. Family Psychology, 14, 304-326. https://doi.org/10.1037/0893-3200.14.2.304

Coddington, R. D. (1999). Coddington Life Events Scales (CLES) Technical Manual. Toronto: Multi-Health Systems.

Crnic, K. A., Gaze, C., \& Hoffman, C. (2005). Cumulative parenting stress across the preschool period: Relations to maternal parenting and child behaviour at age 5. Infant and Child Development, 14, 117-132. https://doi.org/10.1002/icd.384

Das, C. (2009). Recognising ecological contexts of diverse ethnic groups: Experiences of British-Indian adult children of divorce. The International Journal of Diversity in Organisations, Communities and Nations, 9(5), 83-97. https://doi.org/10.1002/icd.384

Dreman, S. (2000). The influence of divorce on children, Journal of Divorce \& Remarriage, 32(3/4), 41-71. https://doi.org/10.1300/J087v32n03_03

Dunn, J., Cheng, H., O'Connor, T. G., \& Bridges, L. (2004). Children's perspectives on their relationships with their nonresident fathers: Influences, outcomes and implications. Journal of Child Psychology and Psychiatry, 45, 553-566. https://doi.org/10.1300/J087v32n03_03

Emery, R. E. (1999). Marriage, divorce, and children's adjustment (2nd ed.). Thousand Oaks, CA: Sage.

Eurostat Statistics Explain (2015). Marriage and divorce statistics. Retrieved from http://ec.europa.eu/eurostat/statisticsexplained/index.php/Marriage_and_divorce_statistics.

Finkelhor, D., Ormrod, R. K., \& Turner, H. A. (2007). Poly-victimization: a neglected component in child victimization. Child Abuse and Neglect, 31, 7-26. https://doi.org/10.1016/j.chiabu.2006.06.008

Fountoulakis, K., Iakovides, B., Iakovides, A., Xristofidis, A., \& Ierodiakonou, C. (1997). The validation of the Life Satisfaction Inventory (LSI) in the Greek population. Psychiatriki, 8, 292-304. [in Greek]

Frisby, B. N., Booth-Butterfield, M., Dillow, M. R., Martin, M. M., \& Weber, K. D. (2012). Face and resilience in 
divorce: The impact on emotion, stress and post-divorce relationships. Journal of Social and Personal Relationships, 29(6), 715-735. https://doi.org/10.1177/0265407512443452

Furstenberg, F., \& Kiernan, K. (2001). Delayed parental divorce: how much do children benefit? Journal of Marriage and the Family, 63, 446-457. https://doi.org/10.1111/j.1741-3737.2001.00446.x

Gagné, M. H., Drapeau, S., Melançon, C., Saint-Jacques, M. C., \& Lépine, R. (2007). Links between parental psychological violence, other family disturbances, and children's adjustment. Family Process, 46(4), 523-542. https://doi.org/10.1111/j.1545-5300.2007.00230.x

Gately, D., \& Schwebel, A. I. (1992). Favorable outcomes in children after parental divorce. Journal of Divorce\& Remarriage, 18, 57-78. https://doi.org/10.1300/J087v18n03_04

Golombok, S. (2000). Parenting: What really counts? London, UK: Routledge.

Greeff, A. P., \& Van Der Merwe, S. (2004). Variables associated with resilience in divorced families. Social Indicators Research, 68, 59-75. https://doi.org/10.1023/B:SOCI.0000025569.95499.b5

Green, L. B., Goodman, L. A., Krupnick, J. L., Corcoran, C. B., Petty, R. M., Stockton, P., \& Stern, N. M. (2000). Outcomes of single versus multiple trauma exposure in a screening sample. Journal of Traumatic Stress, 13, 271-286. https://doi.org/10.1023/A:1007758711939

Greene, S. M., Anderson, E. R., Forgatch, M. S., DeGarmo, D. S., \& Hetherington, E. M. (2011). Risk and resilience after divorce. In F. Walsh, (Ed.), Normal family processes: Growing diversity and complexity (4th ed.). New York: Guilford Press.

Grych, J. H. (2005). Interparental conflicts as a risk factor for child maladjustment: Implications for the development of prevention programs. Family Court Review, 43(1), 97-108. https://doi.org/10.1111/j.1744-1617.2005.00010.x

Guidubaldi, J., Perry, J. D., Nastasi, B. K. (1987). Growing up in a divorced family: Initial and long-term perspectives on children's adjustment. Applied Social Psychology Annual, 7, 202-237.

Hakvoort, E. M., Bos, H. M. VanBalen, F., \& Hermanns, M. A. (2011). Post-divorce relationships in families and children's psychosocial adjustment. Journal of Divorce \& Remarriage, 52, 125-146. https://doi.org/10.1080/10502556.2011.546243

Hetherington, E. M. (1993). An overview of the Virginia Longitudinal Study of Divorce and Remarriage with a focus on early adolescence. Journal of Family Psychology, 7, 39-56. https://doi.org/10.1037/0893-3200.7.1.39

Hetherington, E. M. (1999). Should we stay together for the sake of the children? In E. M. Hetherington (Ed.), Coping with divorce, single parenting and remarriage: A risk and resiliency perspective (pp. 93-116). Mahwah, NJ: Erlbaum.

Hetherington, E. M. (2003). Social support and the adjustment of children in divorced and remarried families. Childhood, 10(2), 217-236. https://doi.org/10.1177/0907568203010002007

Hetherington, E. M., \& Elmore, A. M. (2003). Risk and resilience in children coping with their parents' divorce and remarriage. In S. S. Luthar (Ed.), Resilience and vulnerability: Adaption in the context of childhood adversities (pp. 182-212). New York: Cambridge University. https://doi.org/10.1177/0907568203010002007

Hetherington, E. M., \& Kelly, J. (2002). For better or for worse: Divorce reconsidered. New York: W. W. Norton.

Hetherington, E. M., \& Stanley-Hagan, M. (1999). The adjustment of children with divorced parents: A risk and resiliency perspective. Journal of Child Psychology and Psychiatry, 40, 129-140. https://doi.org/10.1111/1469-7610.00427

Hetherington, E. M., \& Stanley-Hagan, M. (2002). Parenting in divorced and remarried families. In M. Bornstein (Ed.), Handbook of parenting (2nd ed.). Mahwah, NJ: Erlbaum.

Hetherington, E. M., Cox, M., \& Cox, C. R. (1982). Effects of divorce on parents and children. In M. Lamb (Ed.), Nontraditional families (pp. 223-288). Hillsdale, NJ: Erlbaum.

Katz, L. F., \& Woodin, E. M. (2002). Hostility, hostile detachment, and conflict engagement in marriages: effects on child and family functioning. Child Development, 73, 636-651. https://doi.org/10.1111/1467-8624.00428

Kelly, J. B. (2000). Children's adjustment in conflicted marriage and divorce: A decade review of research. Journal of the American Academy of Child and Adolescent Psychiatry, 39(8), 963-973. 
https://doi.org/10.1111/1467-8624.00428

Kelly, J. B., \& Emery, R. E. (2003). Children's adjustment following divorce: Risk and resilience perspectives. Family Relations: Interdisciplinary Journal of Applied Family Studies, 52(4), 352-362. https://doi.org/10.1111/j.1741-3729.2003.00352.x

Kincaid, S. B. \& Caldwell, R. A. (1995). Marital Separation: Causes, coping, and consequence. Journal of Divorce and Remarriage, 22, 109-128. https://doi.org/10.1111/j.1741-3729.2003.00352.x

Kurdek, L. A. (1981). An integrative perspective on children's divorce adjustment. American Psychologist, 36(8), 375-385. https://doi.org/10.1037/0003-066X.36.8.856

Kurdek, L. A. (1988). Social support of divorced single mothers and their children. Journal of Divorce, 11(3/4), 167-188. https://doi.org/10.1300/J279v11n03_12

Lansford, J. E. (2009). Parental divorce and children's adjustment. Perspectives on Psychological Science, 4(2), 140-152. https://doi.org/10.1111/j.1745-6924.2009.01114.x

Lengua, L. J., Wolchik, S. A., \& Braver, S. L. (1995). Understanding children's divorce adjustment from an ecological perspective. Journal of divorce \& remarriage, 22(3/4), 25-53. https://doi.org/10.1111/j.1745-6924.2009.01114.x

Lengua, L. J., Wolchik, S. A., Sandler, I. N., \& West, S. G. (2000). The additive and interactive effects of parenting and temperament in predicting problems of children of divorce. Journal of Clinical Child Psychology, 29, 232-244. https://doi.org/10.1207/S15374424jccp2902_9

Leon, K. (2003). Risk and protective factors in young children's adjustment to parental divorce: A review of the research. Family Relations, 52(3), 258-270. https://doi.org/10.1111/j.1741-3729.2003.00258.x

Linker, J. S., Stolberg, A. L., \& Green, R. G. (1999). Family communication as a mediator of child adjustment to divorce. Journal of Divorce \& Remarriage, 30(1-2), 83-97. https://doi.org/10.1300/J087v30n01_06

Masten, A. S., \& Coatsworth, J. D. (1998). The development of competence in favorable and unfavorable environments: Lessons from successful children. American Psychologist, 53, 205-220. https://doi.org/10.1037/0003-066X.53.2.205

Masten, A. S., Cutuli, J. J., Herbes, J. E., Reed, M. J. (2009). Resilience in development. In S. J. Lopez \& C. R. Snyder (Eds.), The Oxford handbook of positive psychology (pp. 117-132). Oxford, New York: Oxford University Press. https://doi.org/10.1093/oxfordhb/9780195187243.013.0012

McIntosh, J., Burke, S., Dour, N., \& Gridley, H. (2009). Parenting after separation. A position statement prepared for The Australian Psychological Society.

McIntyre, A., Heron, R. L., McIntyre, M. D., Burton, S. J., \& Engler, J. N. (2003). College students from families of divorce: Keys to their resilience. Journal of Applied Developmental Psychology, 24, 17-31. https://doi.org/10.1093/oxfordhb/9780195187243.013.0012

McLanahan, S. (1999). Father absence and the welfare of children. In E. M. Hetherington (Ed.), Coping with divorce, single parenting and remarriage: A risk and resiliency perspective (pp. 117-146). Mahwah, NJ: Erlbaum.

McLoyd, V., Harper, C., \& Copeland, N. K. (2001). Does gender moderate the effects of marital conflict on children? In J. Grych \& F. Fincham (Eds.), Interparental conflict and child development (pp. 9-38). New York: Cambridge University Press.

Miller, A. C., Gordon, R. M., Daniele, R. J., \& Diller, L. (1992). Stress, appraisal, and coping in mothers of disabled and nondisabled children. Journal of Pediatric Psychology, 17(5), 587-605. https://doi.org/10.1093/jpepsy/17.5.587

Miller, N. B., Smerglia, V. L., Gaudet, D. S., \& Kitson, G. C. (1998). Stressful life events, social support, and the distress of widowed and divorced women. Journal of Family Issues, 19(2), 181-203. https://doi.org/10.1093/jpepsy/17.5.587

Nair, H., \& Murray, A. D. (2005). Predictors of attachment security in preschool children from intact and divorced families. Journal of Genetic Psychology, 166, 245-263. https://doi.org/10.1093/jpepsy/17.5.587

Nunes-Costa, R. A., Lamela, D. J. \& Figueiredo, B. F. (2009). Psychosocial adjustment and physical health in children of divorce. Journal of Pediatrics (Rio J), 85(5), 385-396. https://doi.org/10.2223/JPED.1925 
O'Connor, T. G. (2003). Vulnerability and resilience in children in divorced and remarried families. In R. M. Gupta \& D. S. Parry-Gupta (Eds.), Children and parents: Clinical issues for psychologists and psychiatrists (pp. 180-206). London: Whurr Publishers.Petrogiannis, K. (1995). Psychological development at 18 months of age as a function of child care experience in Greece. Doctoral dissertation. Cardiff: University of Wales.

Petrogiannis, K (2003). The study of human development: the ecosystemic perspective. A presentation of Urie Bronfenbrenner's theory based on findings from the international research. Athens: Kastaniotis [in Greek].

Petrogiannis, K. \& Bardos, A. (2011). The development of the Affective Wellness Scale for preschool children. In P. Giavrimis, E. Papanis, \& A. Viki (Eds.), Research and educational act in special education (vol. I). Thessaloniki: Kyriakides [in Greek].

Pierce, S. H., Alfonson, E. M., \& Garrison, M. E. B. (1999). Examining proximal processes in young children's home environments: A preliminary report. Family Consumer Sciences Research Journal, 27, 3-34. https://doi.org/10.1177/1077727X980271001

Porter, B., \& O'Leary, K. D. (1980). Marital discord and childhood behavior. Journal of Abnormal Child Psychology, 8, 287-295. https://doi.org/10.1007/BF00916376

Pruett, M. K., Williams, T. Y., Insabella, G., \& Little, T. D. (2003). Family and legal indicators of child adjustment to divorce among families with young children. Journal of Family Psychology, 17(2), 169-180. https://doi.org/10.1037/0893-3200.17.2.169

Rhoades, K. A. (2008). Children's response to inter-parental conflict: a meta-analysis of their associations with child adjustment. Child Development, 79, 1942-1956. https://doi.org/10.1111/j.1467-8624.2008.01235.x

Rogers, K. N. (2004). A theoretical review of risk and protective factors related to post-divorce adjustment in

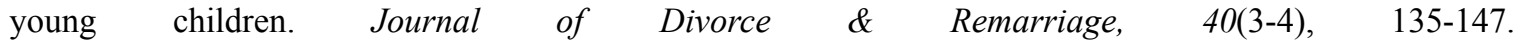
https://doi.org/10.1300/J087v40n03_09

Rushena, E., Prior, M., Sanson, A., \& Smart, D. (2005). A longitudinal study of adolescent adjustment following family transitions. Journal of Child Psychology and Psychiatry, 46, 353-363. https://doi.org/10.1111/j.1469-7610.2004.00369.x

Shifflett, K., \& Cummings, E. M. (1999). A program for educating parents about the effects of divorce and conflict on children: An initial evaluation. Family relations, 48(1), 79-89. https://doi.org/10.2307/585685

Simons, R. L., Lin, K. H., Gordon, L. C., Conger, R. D., \& Lorenz, F. O. (1999). Explaining the higher incidence of adjustment problems among children of divorce compared with those in 2-parent families. Journal of Marriage and Family, 61, 1020-1033. https://doi.org/10.2307/354021

Strohschein, L. (2005). Parental divorce and child mental health trajectories. Journal of Marriage and Family, 67, 1286-1300. https://doi.org/10.1111/j.1741-3737.2005.00217.x

Sun, Y., \& Li , Y. (2002). Children's well-being during parents' marital disruption process: A pooled time-series analysis. Journal of Marriage and Family, 64(2), 472-488. https://doi.org/10.1111/j.1741-3737.2002.00472.x

Thoennes, N., \& Pearson, J. (1999). Parent education in the domestic relations court. Family Court Review, 37(2), 195-218. https://doi.org/10.1111/j.174-1617.1999.tb00536.x

Thompson, R. J., Gustafson, K. E., Hamlett, K. W., \& Spock, A. (1992). Stress, coping, and family functioning in the psychological adjustment of mothers of children and adolescents with cystic fibrosis. Journal of Pediatric Psychology, 17(5), 573-585. https://doi.org/10.1111/j.174-1617.1999.tb00536.x

Tschann, J. M., Johnston, J. R., Kline, M., \& Wallerstein, J. S. (1990). Conflict, loss, change and parent-child relationships: Predicting children's adjustment during divorce. Journal of Divorce, 13, 1-22. https://doi.org/10.1300/J279v13n04_01

Umberson, D. (1992). Gender, marital status and the social control of health behavior. Social science \& medicine, 34(8), 907-917. https://doi.org/10.1016/0277-9536(92)90259-S

Vandewater, E. A., \& Lansford, J. E. (1998). Influences of family structure and parental conflict on children's well-being. Family Relations, 47(4), 323-330. https://doi.org/10.2307/585263

Videon, T. M. (2002). The effects of parent-adolescent relationships and parental separation on adolescent well-being. Journal of Marriage and Family, 64(2), 489-503. https://doi.org/10.1111/j.1741-3737.2002.00489.x

Wallerstein, J., Lewis, J., \& Packer-Rosenthal, S. (2013). Mothers and their children after divorce: Report from a 
25-year longitudinal study. Psychoanalytic $\quad$ Psychology, $\quad 30(2), \quad 167$. https://doi.org/10.1111/j.174-1617.1998.tb00519.x

Weaver, J. M., \& Schofield, T. J. (2015). Mediation and moderation of divorce effects on children's behavior problems. Journal of Family Psychology, 29(1), 39. https://doi.org/10.1037/fam0000043

Wels, P. M. A., \& Robbroeckx, L. M. H. (1996). Handleiding van de Nijmeegse Vragenlijst Voor de Opvoedingssituatie (NVOS) [Manual for the Nijmegen Child-Rearing Situation Questionnaire]. Lisse: Swets \& Zeitlinger.

\section{Copyrights}

Copyright for this article is retained by the author(s), with first publication rights granted to the journal.

This is an open-access article distributed under the terms and conditions of the Creative Commons Attribution license (http://creativecommons.org/licenses/by/4.0/). 